\title{
PENGARUH KARAKTERISTIK PEKERJAAN DAN KOMITMEN ORGANISASI TERHADAP MOTIVASI SERTA DAMPAKNYA TERHADAP KINERJA PEGAWAI PADA DINAS KELAUTAN DAN PERIKANAN PROVINSI JAMBI.
}

\author{
${ }^{1}$ Dessy Jusfartinah, ${ }^{2}$ Tetty Asnawi, dan ${ }^{3}$ Arna Suryani \\ ${ }^{1}$ Alumni Program Magister Manajemen FE UNBARI, ${ }^{2}$ Dosen Program Magister \\ Manajemen FE UNBARI, dan ${ }^{3}$ Dosen Program Magister Manajemen FE \\ UNBARI
}

\begin{abstract}
The purpose of this research is to gain an overview of karakeristik of work, organizational commitment, motivation and performance of employees at the Department ofmarine and Fisheries province of Jambi and to know the influence of characteristicsof work and commitment the Organization's response to the employee motivation and performance, as well as to know the influence of motivation on performance. To address the research objectives then requires the author studies the theory related to the variable of research i.e. the theory of characteristics of work, organizational commitment, motivation and performance. In addition the author also searched for relevant earlier research in the form of articles/journals and previous thesis to supportthis research. The population in this research is the Department of Marine and fisheries officer province of Jambi that add up to 57 employees. Due to the number of population in this study less than 100 people then in this research sampling method using the method of census. Analysis techniques using path analysis to see the direct and indirect influence, and was succeeded by testing RSquare and hypothesis testing partially and simultaneous with $t$ test and F-test of the test path analysis is done, the results Research shows that the characteristics of the work and the commitment of the Organization to have an impact on the motivation and performance of employees. Where on the basis of the results of the test $t$ (partial) and $F$ (Simultaneous) tests showed that the characteristics of the work and the commitment of the Organization had a significant and positive influence towards motivation and performance, so did motivasijuga have influence significant and positive on performance. This explains that the characteristics of the work and commitment of organizations that either have a positive influence in providing and enhancing motivation to work-have implications for improved performance against employees at the Department of marine and Fisheries The Province Of Jambi. This research makes some conclusions based on the results of research of characteristics of work, organizational commitment, motivation and performance of employees at the Department of marine and Fisheries province of Jambi in good enough conditions, characteristics the work and the commitment of the Organization a positive and significant effect against the motivation of working either partially or simultaneously, the characteristics of the job and the Organization's commitment to a positive and significant effect on performance of goodemployees partially or simultaneously, work motivation affects employee performance, and the characteristics of the work and commitment of organizations collectivelythrough motivation can direct and indirect effect against against performance employees at the Department of marine and Fisheries province of Jambi.
\end{abstract}

Keywords: organizational commitment, Job Characteristics, Motivasidan performance.

\section{PENDAHULUAN}

Manajemen sumber daya manusia memiliki peranan dan fungsi yang penting dalam setiap organisasi. Karena dengan fungsi tersebut organisasi akan lebih baik dalam mengelola, mengatur, serta memanfaatkan sumber daya manusianya agar dapat berfungsi secara maksimal sehingga tujuan organisasi dapat tercapai sesuai dengan harapan yang diinginkan (Asnawi, 2016:1). 
Salah satu aspek pokok dari pekerjaan manajemen yang berkaitan dengan sumberdaya manusia adalah aspek yang berkaitan dengan kinerja pegawai dan bagian manajemen yang mengelola ini lebih dikenal dengan sebutan manajemen kinerja.

Secara teori terdapat banyak sekali faktor-faktor yang berhubungan dengan kinerja pegawai. Faktor-faktor tersebut bisa saja bersumber dari lingkungan (termasuk organisasi) maupun faktor-faktor yang berasal dari dalam diri pegawai sendiri. Faktor lingkungan bisa saja bersumber dari organisasi, diantaranya adalah karakteristik pekerjaan, sementara faktor yang berasal dari pegawai itu sendiri salah satu diantaranya adalah watak, kelakuan dan kualifikasi pribadi dari pegawai yang dalam hal ini diimplementasikan dalam bentuk komitmen pegawai dan motivasi.

Karakteristik pekerjaan pada dasarnya adalah menyangkut perancangan sistem kerja pada para pegawai atau dikenal sebagai karakteristik pekerjaan.Pekerjaan yang monoton atau secara rutin hanya menggunakan jenis keahlian saja, misalnya, dapat membuat pegawai bosan dengan pekerjaanya dibandingkan dengan para pegawai yang bekerja menggunakan berbagai variasi pekerjaan.

Karakteristik pekerjaan merupakan upaya mengidentifikasi karakteristik tugas dari suatu pekerjaan, bagaimana karakteristik itu digabung untuk membentuk pekerjaan yang berbeda dengan hubungannya dengan motivasi, kepuasan kerja dan kinerja karyawan. Menurut Hackman dan Oldham dalam Frismandiri, D (2007) karakteristik pekerjaan memiliki lima faktor yaitu variasi keterampilan (skill variety), kejelasan tugas (task identity), kepentingan tugas (task significance), kewenangan dan tanggung jawab (autonomy), dan umpan balik (feedback). Karakteristik pekerjaan memiliki hubungan yang sangat erat terhadap kinerja, sehingga kinerja atau pencapaian tugas yang harus di selesaikan seseorang yang bekerja di organisasi akan sangat berhubungan dengan faktorfaktor karakteristik pekerjaan.

Hal ini juga didukung oleh hasil penelitian yang telah dilakukan oleh Lubis, Y (2012), Wulandari, S., Sulianti, D., dan Sunardi (2015), Zunaidah (2010), dan Frismandiri, D (2007) yang menyatakan bahwa karakteristik pekerjaan mempunyai pengaruh signifikan terhadap kinerja dan karakteristik pekerjaan memberikan konstribusi yang cukup kuat pada kinerja.

Faktor penting lainnya yang berkaitan dengan pegawai adalah faktor yang berasal dari para pegawai itu sendiri. Faktor yang berkaitan dengan sikap pegawai dalam menghadapi pekerjaan merupakan diantara faktor-faktor yang memainkan peran penting bagi kinerja pegawai.Di antara faktor yang berhubungan dengan sikap pegawai adalah komitmen keorganisasian dari para pegawai.

Banyak sudah penelitian yang dilakukan mengungkapkan jika komitmen pegawai memiliki pengaruh terhadap kinerja pegawai, diantaranya penelitian yang dilakukan oleh Frismandiri, D (2007), Safrizal, Said, M., dan Syafruddin, C (2014), Abrivianto, P.O., Swasto, B., dan Utami, H.N. (2014), dan Suwardi dan Utomo, J. (2011) dimana hasil penelitiannya menyatakan secara signifikan dan positif kinerja dipengaruhi oleh komitmen organisasi. Artinya apabila pegawai memiliki komitmen yang tinggi terhadap organisasi tempat mereka bernaung, maka dengan senantiasa pegawai tersebut akan mampu memberikan hasil kerja yang optimal.

Selanjutnya adapun faktor lain yang berhubungan dengan sikap pegawai adalah motivasi. Pada dasarnya setiap aktifitas yang dilakukan oleh seseorang 
didorong oleh suatu kekuatan dalam diri orang tersebut, kekuatan pendorong inilah yang disebut motivasi. Motivasi kerja pegawai dalam suatu organisasi dapat dianggap sederhana dan dapat pula menjadi masalah yang kompleks, karena pada dasarnya manusia mudah untuk dimotivasi dengan memberikan apa yang menjadi keinginannya. Masalah motivasi kerja dapat menjadi sulit dalam menentukan imbalan dimana apa yang dianggap penting bagi seseorang karena sesuatu yang penting bagi seseorang belum tentu penting bagi orang lain.

Menurut Maslow dalam Triatna (2015:86), kebutuhan seseorang itu terentang dari kebutuhan yang paling bawah sampai kebutuhan yang paling tinggi. Maslow mengemukakan lima hierarki kebutuhan bagi manusia, yaitu kebutuhan dasar, keamanan, sosial, penghargaan, dan aktualisasi diri. Apabila lima kebutuhan ini dapat terpenuhi, maka dengan sendiri seseorang akan mampu memberikan hasil kerja yang optimal.

Beberapa hasil penelitian mengemukakan bahwa kinerja dipengaruhi oleh motivasi, diantaranya yakni penelitian yang dilakukan oleh Wulandari, S., Sulianti, D., dan Sunardi (2015), Abrivianto, P.O., Swasto, B., dan Utami, H.N. (2014), Suwardi dan Utomo, J. (2011), dan Asyenda, Y (2013) mengungkapkan bahwa motivasi kerja juga akan mampu mempengaruhi dan meningkatkan kinerja. Artinya dengan memiliki motivasi kerja yang tinggi akan mampu memberikan hasil kerja yang maksimal.

Sesuai dengan permasalahan yang diajukan dalam penelitian, maka tujuan dari peneltian ini yaitu "gambaran karakteristik pekerjaan, komitmen pegawai, motivasi dan kinerja pegawai pada Dinas Kelautan dan Perikanan Provinsi Jambi, serta mengetahui pengaruh karakteristik pekerjaan dan komitmen organisasi terhadap motivasi kerja dan kinerja pegawai baik secara parsial maupun secara simultan."

\section{TINJAUAN PUSTAKA}

\section{Landasan Teori}

\section{a. Karakteristik Pekerjaan}

Karakteristik pekerjaan adalah upaya mengidentifikasikan karakteristik tugas dari pekerjaan, bagaimana karakteristik itu digabung untuk membentuk pekerjaan yang berbeda dan hubungannya dengan motivasi, kepuasan kerja dan kinerja karyawan (Robbins, 2009).

Model karakteristik pekerjaan (job characteristic models) merupakan suatu pendekatan terhadap pemerkayaan pekerjaan (job enrichment). Program pemerkayaan pekerjaan berusaha merancang pekerjaan dengan cara membantu para pemangku jabatan memuaskan kebutuhan mereka akan pertumbuhan, pengakuan, dan tanggung jawab. Pemerkayaan pekerjaan menambahkan sumber kepuasan kepada pekerjaan.Metode ini meningkatkan tanggung jawab, otonomi, dan kendali (Simamora, 2006).

Robbins (2009) menjelaskan tentang model karakteristik pekerjaan bahwa setiap pekerjaan dapat dideskripsikan dalam lima dimensi pekerjaan inti, yaitu sebagai berikut: 1) Keanekaragaman Keterampilan; 2) Identitas tugas; 3) Pentingnya tugas; 4) Otonomi; dan 5) Umpan balik.

Kelima dimensi dari karakteristik kerja tersebut menciptakan tingkat reaksi psikologis seseorang tentang makna, tanggung jawab serta pengetahuan yang dihasilkan dari pekerjaan tersebut yang pada akhirnya berdampak pada motivasi, kinerja, dan kepuasan kerja pegawai serta tingkat kemangkiran dan tingkat keluar masuknya pegawai. 


\section{b. Komitmen Organisasi}

Komitmen organisasi merupakan identifikasi dan keterlibatan seseorang yang relatif kuat terhadap organisasi. Komitmen organisasional adalah keinginan anggota organisasi untuk tetap mempertahankan keanggotaannya dalam organisasi dan bersedia berusaha keras bagi pencapaian tujuan organisasi (Sopiah, 2008). Sedangkan Robbins (2009) mengemukakan komitmen organisasi merupakan salah satu sikap yang merefleksikan perasaan suka atau tidak suka terhadap organisasi tempat bekerja.

Mathis dan Jackson dalam Sopiah (2008) memberikan definisi, "Organizational Commitment is the degree to which employees believe in and accept organizational goals and desire to remaint with the organization". (Komitmen organisasional adalah derajat yang mana karyawan percaya dan menerima tujuan-tujuan organisasi dan akan tetap tinggal atau tidak akan meninggalkan organisasi).

Allen dan Meyer dalam Triatna (2015) mendefinisikan komitmen organisasi sebagai sebuah konsep yang memiliki tiga dimensi, yaitu affective, normative dan continuance commitment.Affective commitment adalah tingkat seberapa jauh seorang karyawan secara emosi terikat, mengenal dan terlibat dalam organisasi.Continuance commitment adalah suatu penilaian terhadap biaya yang terkait dengan meninggalkan organisasi. Normative commitment adalah merujuk kepada tingkat seberapa jauh seseorang secara psychological terikat untuk menjadi karyawan dari sebuah organisasi yang didasarkan kepada perasaan seperi kesetiaan, afeksi, kehangatan, kepemilikan, kebanggan, kesenangan, kebahagiaan dan lainlain.

\section{c. MotivasiKerja}

Motivasi kerja merupakan kombinasi kekuatan psikologis yang kompleks dalam diri masing-masing orang (Wibowo, 2014:109).Luthan (2006:270) mengemukakan bahwa motivasi adalah proses yang dimulai dengan defisiensi fisiologis atau psikologis yang menggerakan perilaku atau dorongan yang ditujukan untuk tujuan atau insentif. Dengan demikian, kunci untuk memahami proses motivasi bergantung pada pengertian dan hubungan antara kebutuhan, dorongan dan insentif.

Kemudian Sutrisno (2012:110) juga menjelaskan motivasi adalah sesuatu yang menimbulkan semangat atau dorongan kerja. Motivasi adalah pemberian daya penggerak yang menciptakan kegairahan kerja seseorang, agar mereka mau bekerja sama, bekerja efektif, dan terintegrasi dengan segala daya upayanya untuk mencapai kepuasan.

Selain itu Robbin dan Judge (2015:127) mendefinisikan motivasi sebagai proses yang menjelaskan mengenai kekuatan, arah, dan ketekunan seseorang dalam upaya untuk mencapai tujuan. Oleh karena motivasi secara umum adalah berkaitan dengan upaya menuju setiap tujuan, kita kan mempersempit fokus menjadi tujuan organisasi terhadap perilaku terkait pekerjaan.

Lebih lanjut Maslow dalam Triatna (2015:86) mengemukakan adapun aspek-aspek yang dinilai untuk mengukur motivasi yaitu a) Fisiologis; b) keamanan; c) sosial; d) penghargaan; dan e) aktualisasi diri, 


\section{d. Kinerja}

Kinerja merupakan perilaku nyata yang ditampilkan setiap orang sebagai prestasi kerja yang dihasilkan oleh karyawan sesuai dengan perannya dalam organisasi.Kinerja karyawan merupakan suatu hal yang sangat penting dalam upaya organisasi untuk mencapai tujuan (Rivai dan Sagala, 2009). Sedangkan menurut Hasibuan (2009) mendefinisikan kinerja sebagai suatu hasil kerja yang dicapai seseorang dalam melaksanakan tugastugas yang dibebankan kepadanya yang didasarkan atas kecakapan, pengalaman, kesungguhan serta waktu.

Istilah kinerja berasal dari kata job performance atau actual performance (prestasi kerja atau prestasi sesungguhnya yang dicapai seseorang) yaitu hasil kerja secara kualitas dan kuantitas yang dicapai oleh seorang pegawai dalam melaksanakan tugasnya sesuai dengan tanggung jawab yang diberikan kepadanya (Mangkunegara, 2014). Pengertian tersebut memberikan pemahaman bahwa kinerja merupakan suatu perbuatan atau perilaku seseorang dalam pelaksanaan tugasnya, yang dapat diamati dan dinilai oleh orang lain.

Lebih lanjut Mangkunegara (2014) menyatakan bahwa pada umumnya kinerja dibedakan menjadi dua, yaitu kinerja individu dan kinerja organisasi. Kinerja individu adalah hasil kerja pegawai baik dari segi kualitas maupun kuantitas berdasarkan standar kerja yang telah ditentukan, sedangkan kinerja organisasi adalah gabungan dari kinerja individu dan kinerja kelompok.

Menurut Rivai dan Sagala (2009) adapun aspek-aspek yang dinilai untuk mengukur kinerja seseorang berdasarkan hasil studi Lazer dan Wikstrom (1997) dapat dikelompokkan sebagai berikut: 1) Kemampuan teknis; 2) Kemampuan konseptual; dan 3) Kemampuan hubungan interpersonal.

\section{Kerangka Pemikiran}

Kerangka pemikiran merupakan model konseptual tentang bagaimana teori berhubungan berbagai faktor yang telah diidentifikasi sebagai masalah penting (Sugiyono, 2012). Berdasarkan tujuan penelitian, kajian pustaka, penelitian terdahulu dan hubungan antar variabel maka kerangka analisis dalam penelitian ini disajikan dalam bentuk Gambar 2.1. Dimana variabel karakteristik pekerjaan dan komitmen organisasi merupakan variabel independent, variabel kinerja sebagai variabel dependent dan variabel motivasikerja sebagai variabel intervening, atau variabel yang memediasi antara variabel independent dengan variabel dependent.

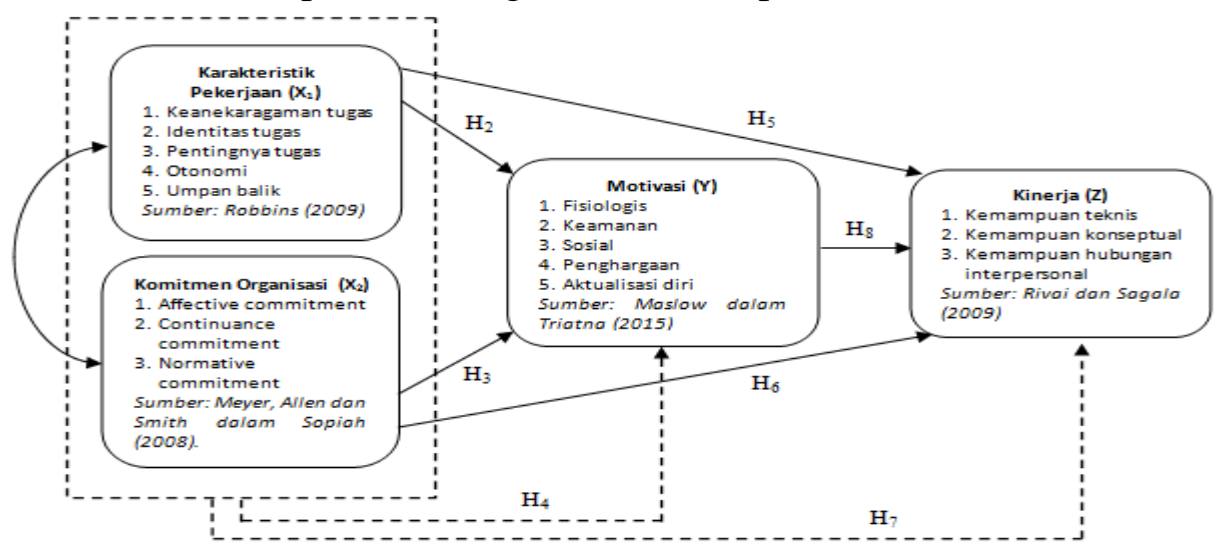

Gambar 1.Kerangka Berpikir 


\section{Hipotesis}

Berdasarkan permasalahan yang diteliti, maka ditarik suatu hipotesis sebagai berikut:

H1: Diduga karakteristik pekerjaan, komitmen pegawai, motivasi dan kinerja pegawai pada Dinas Kelautan dan Perikanan Provinsi Jambi dalam kondisi baik.

$\mathbf{H}_{2}$ : Karakteristik pekerjaan dan komitmen organisasi secara parsial dan simultan berpengaruh signifikan terhadap motivasi kerja.

$\mathbf{H}_{3}$ : Karakteristik pekerjaan dan komitmen organisasi secara parsial dan simultan berpengaruh signifikan terhadap kinerja.

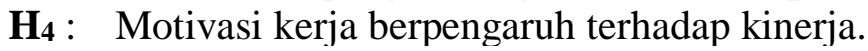

H5 : Karakteristik pekerjaan dan komitmen organisasi melalui motivasi berpengaruh signifikan terhadap kinerja.

\section{METODE PENELITIAN}

\section{Metode Penelitian}

Metode penelitian yang digunakan adalah metode penelitian survey dengan membuat angket kepada responden (pegawai) yang akan menjawab pernyataan-pernyataan tentang pengaruh karakteristik pekerjaan, komitmen organisasi, motivasi kerja dan Kinerja pegawai pada Dinas Kelautan dan Perikanan Provinsi Jambi. Tingkat eksplanasi (level of explanation) penelitian ini adalah penelitian deskriptif dan verifikatif. Adapun alat analisis yang digunakan dalan penelitian ini adalah alat analisis jalur (path analysis).

\section{Populasi dan Sampel}

Populasi dalam penelitian ini adalah karyawan pada Dinas Kelautan dan Perikanan Provinsi Jambi yang berjumlah 57 pegawai.Dikarenakan jumlah populasi dalam penelitian ini kurang dari 100 orang maka dalam penelitian ini metode pengambilan sampel menggunakan metode sensus dimana semua pegawai dijadikan sebagai sampel penelitian, sehingga jumlah sampel dalam penelitian ini adalah sebanyak 57 orang pegawai.

\section{MetodePenelitian}

Berdasarkan tujuan penelitian maka metode penelitian yang digunakan adalah explanatory research (penelitian penjelasan).Explanatory research merupakan penelitian yang dilakukan untuk menjelaskan hubungan kausal antara variabel-variabel penelitian melalui pengujian hipotesis (Singarimbun dan Effendi, 2012). Pendekatan penelitian yang digunakan dalam penelitian ini adalah pendekatan kuantitatif. Proses pendekatan kuantitatif berawal dari teori, yang diturunkan menjadi hipotesis penelitian dengan menggunakan logika deduktif yang disertai dengan pengukuran dan operasionalisasi variabel. Selanjutnya dilakukangeneralisasi berdasarkan hasil data statistik sehingga dapat diambil kesimpulan sebagai temuan penelitian untuk menjawab permasalahan yang sedang dihadapi. Namun dilakukan analisis terlebih dahulu dilakukan uji instrumen kuesioner dengan uji validitas dan reliabilitas.

\section{Metode Analisis}

\section{a. Metode Deskriptif (Kualitatif)}

Adapun langkah-langkah yang dilakukan adalah sebagai berikut:

1) Setiap indikator yang dinilai oleh responden, diklasifikasikan dalam lima alternatif jawaban dengan menggunakan skala ordinal yang menggambarkan peringkat jawaban. 
2) Dihitung total skor setiap variabel/subvariabel = jumlah skor dari seluruh indikator variabel untuk semua responden.

3) Dihitung skor setiap variabel/subvariabel = rata-rata dari total skor.

4) Untuk mendeskripsikan jawaban responden, juga digunakan statistik deskriptif seperti distribusi frekuensi dan tampilan dalam bentuk tabel ataupun grafik.

\section{b. Analisis Jalur (Path Analysis)}

Penelitian ini menggunakan analisis analisis jalur (Path Analysis). Sunyoto (2011:96) menulis bahwa analisis jalur ialah suatu teknik untuk menganalisis sebab akibat yang terjadi pada regresi berganda jika variabel bebasnya mempengaruhi variabel tergantung tidak hanya langsung tetapi juga secara tidak langsung.

Path Analysis adalah teknik statistik yang digunakan untuk menguji hubungan struktural atau kausal antara dua atau lebih variabel, dimana dalam hal ini variabel yang dimaksud adalah karakteristik pekerjaan, komitmen pegawai, dan kinerja pegawai dan satu variabel intervening yaitu motivasi. Variable intervening merupakan variabel antara atau mediasi yang fungsinya memediasi hubungan antara variabel independen kepada variabel dependen.Untuk menguji variabel intervening digunakan metode analisis jalur, sebagai perluasan dari analisis regresi linier berganda.

Diagram jalur dalam penelitian terdiri dari tiga sub structural,dimana $\mathrm{X}_{1}$ dan $\mathrm{X}_{2}$ adalah variabel eksogen (exogenous) yaitu variabel yang tidak ada penyebab eksplisit nya, variabel ini berfungsi sebagai variabel bebas/penyebab terhadap variabel urutan sesudah nya yaitu $\mathrm{Y}$ serta $\mathrm{Z}$ sebagai variabel endogen (endogenous) dimana $\mathrm{Y}$ merupakan variabel perantara dan $\mathrm{Z}$ adalah variabel tergantung.

\section{c. Uji Hipotesis}

\section{1) Koefisien Determinasi $\left(\mathbf{R}^{2}\right)$}

Koefisien Determinasi (KD) pada intinya mengukur seberapa jauh kemampuan model dalam menerangkan variasi variabel terikat. Nilai koefisien determinasi adalah dari nol (0) dan satu (1), nilai $\mathrm{R}^{2}$ yang kecil berarti kemampuan variabel-variabel independent dalam menjelaskan variasi variabel dependent amat terbatas. Nilai yang mendekati satu berarti variabel-variabel independent memberikan hampir semua informasi yang dibutuhkan untuk memprediksikan variasi variabel dependent. Analisis koefisien determinasi digunakan untuk melihat seberapa besar variabel independent $(\mathrm{X})$ berpengaruh terhadap variabel dependent $(\mathrm{Y})$ yang dinyatakan dalam persentase.

2) Uji t (Parsial)

Uji ini digunakan untuk mengetahui secara parsial seberapa besar pengaruh tingkat signifikansi variabel bebas (independent) terhadap variabel terikat (dependent). Keputusan yang diambil pada uji t juga berdasarkan perbandingan antara nilai signifikansi yang didapatkan dengan derajat tingkat kepercayaan $(\alpha)$ yaitu 0,05 .

- Apabila $t_{\text {hitung }}>\mathrm{t}_{\text {tabel }}$ atau alpha $<0.05$, maka tolak $\mathrm{H}_{0}$ dan terima $\mathrm{H}_{1}$

- Apabila $t_{\text {hitung }}<\mathrm{t}_{\text {tabel }}$ atau alpha $>0.05$, maka terima $\mathrm{H}_{0}$ dan tolak $\mathrm{H}_{1}$

\section{3) Uji F (Simultan)}

Uji simultan atau uji $F$ digunakan untuk mengetahui apakah seluruh variabel bebas (independent variable) secara simultan mempunyai pengaruh terhadap variabel terikat (dependent variable).Pengujian ini 
dilakukan dengan membandingkan nilai $F_{\text {hitung }}$ dengan $F_{\text {tabel }}$ pada derajat kesalahan 5\%.kriteria pengujian hipotesis secara simultan dilakukan dengan membandingkan nilai signifikansi $0,05(5 \%)$ sebagai berikut.

- Apabila $\mathrm{F}_{\text {hitung }}>\mathrm{F}_{\text {tabel }}$ atau alpha $<0.05$, maka tolak $\mathrm{H}_{0}$ dan terima $\mathrm{H}_{1}$

- Apabila $\mathrm{F}_{\text {hitung }}<\mathrm{F}_{\text {tabel }}$ atau alpha $>0.05$, maka terima $\mathrm{H}_{0}$ dan tolak $\mathrm{H}_{1}$

\section{HASIL DAN PEMBAHASAN}

\section{Hasil Deskripsi Jawaban Responden Atas Variabel Penelitian}

a. Deskripsi Data Variabel Karakteristik Pekerjaan $\left(\mathbf{X}_{1}\right)$

Dari hasil deskriptifdiketahui bahwa karakteristik pekerjaan termasuk pada range 148,2-193,7 berada pada Kriteria Cukup Baik. Yang menjelaskan bahwasanya karakteritik pekerjaan pegawai pada Dinas Kelautan dan Perikanan Provinsi Jambi sudah cukup sesuai dengan pekerjaan yang dilaksanakannya. Temuan ini menunjukan hasil yang sama dengan pengamatan awal yang dilakukan yang menunjukan masih adanya pegawai yang mengeluh bosan dalam menghadapi rutinitas kerja, otonomi dalam melakukan tugas yang dirasakan relatif minim, dan kekurang sesuaian antara tugas dengan harapan-harapannya.

\section{b. Deskripsi Data Komitmen Organisasi $\left(\mathrm{X}_{2}\right)$}

Dari hasil deskriptif diketahui bahwa komitmen organisasi termasuk pada range 148,2-193,7 berada pada Kriteria Cukup Baik. Yang menjelaskan bahwasanya pegawai pada Dinas Kelautan dan Perikanan Provinsi Jambimemiliki komitmen yang cukup tinggi dalam bekerja pada organisasi tempat mereka bernaung

\section{c. Deskripsi Data Variabel Motivasi Kerja (Y).}

Dari hasil deskriptif diketahui bahwa motivasi kerja termasuk pada range 148,2-193,7 berada pada Kriteria Cukup Baik. Yang menjelaskan bahwasanya pegawai pada Dinas Kelautan dan Perikanan Provinsi Jambimemiliki motivasi kerja yang cukup tinggi dalam melaksanakan pekerjaannya.

\section{d. Deskripsi Data Variabel Kerja (Z).}

Dari hasil deskriptif diketahui bahwa kinerja termasuk pada range 193,8 - 239,3 berada pada Kriteria Baik. Yang menjelaskan bahwasanya kinerja pegawai pada Dinas Kelautan dan Perikanan Provinsi Jambi sudah berlangsung dengan baik.

\section{Analisis Jalur (Path Analisis)}

Untuk menjawab tujuan-tujuan dalam penelitian ini, struktur utama dalam model penelitian di pecah menjadi tiga sub struktur. Dimana untuk menjawab hipotesis 2 dengan sub struktur pertama, untuk menjawab hipotesis 3 dengan menggunakan sub struktur kedua, danuntuk menjawab hipotesis4 dengan menggunakan sub struktur ketiga. Berikut ini merupakan output SPSS dari tiga struktur yang dirangkum pada tabel berikut. 
Tabel 1.Output SPSS Tiga Sub Struktur.

\begin{tabular}{|c|c|c|c|c|c|c|}
\hline \multirow[t]{2}{*}{ Model } & \multicolumn{2}{|c|}{$\begin{array}{l}\text { Unstandardized } \\
\text { Coefficients }\end{array}$} & \multirow[t]{2}{*}{ Beta } & \multirow[t]{2}{*}{$\mathbf{t}$} & \multirow[t]{2}{*}{$\mathbf{F}$} & \multirow[t]{2}{*}{ Sig. } \\
\hline & B & Std.Error & & & & \\
\hline $\mathrm{X} 1-\mathrm{Y}$ & 0.562 & 0.099 & 0.398 & 5.650 & - & 0.000 \\
\hline $\mathrm{X} 2-\mathrm{Y}$ & 0.551 & 0.063 & 0.621 & 8.816 & - & 0.000 \\
\hline$X 1, X 2-Y$ & - & - & - & - & 113.076 & 0.000 \\
\hline $\mathrm{X} 1-\mathrm{Z}$ & 0.501 & 0.107 & 0.504 & 4.674 & - & 0.000 \\
\hline $\mathrm{X} 2-\mathrm{Z}$ & 0.212 & 0.067 & 0.339 & 3.146 & - & 0.003 \\
\hline $\mathrm{X} 1, \mathrm{X} 2-\mathrm{Z}$ & - & - & - & - & 32.952 & 0.000 \\
\hline $\mathrm{X} 3-\mathrm{Z}$ & 0.504 & 0.066 & 0.715 & 7.582 & - & 0.000 \\
\hline
\end{tabular}

Hasil output diatas di masukkan ke dalam gambar persamaan struktural sebagai berikut:

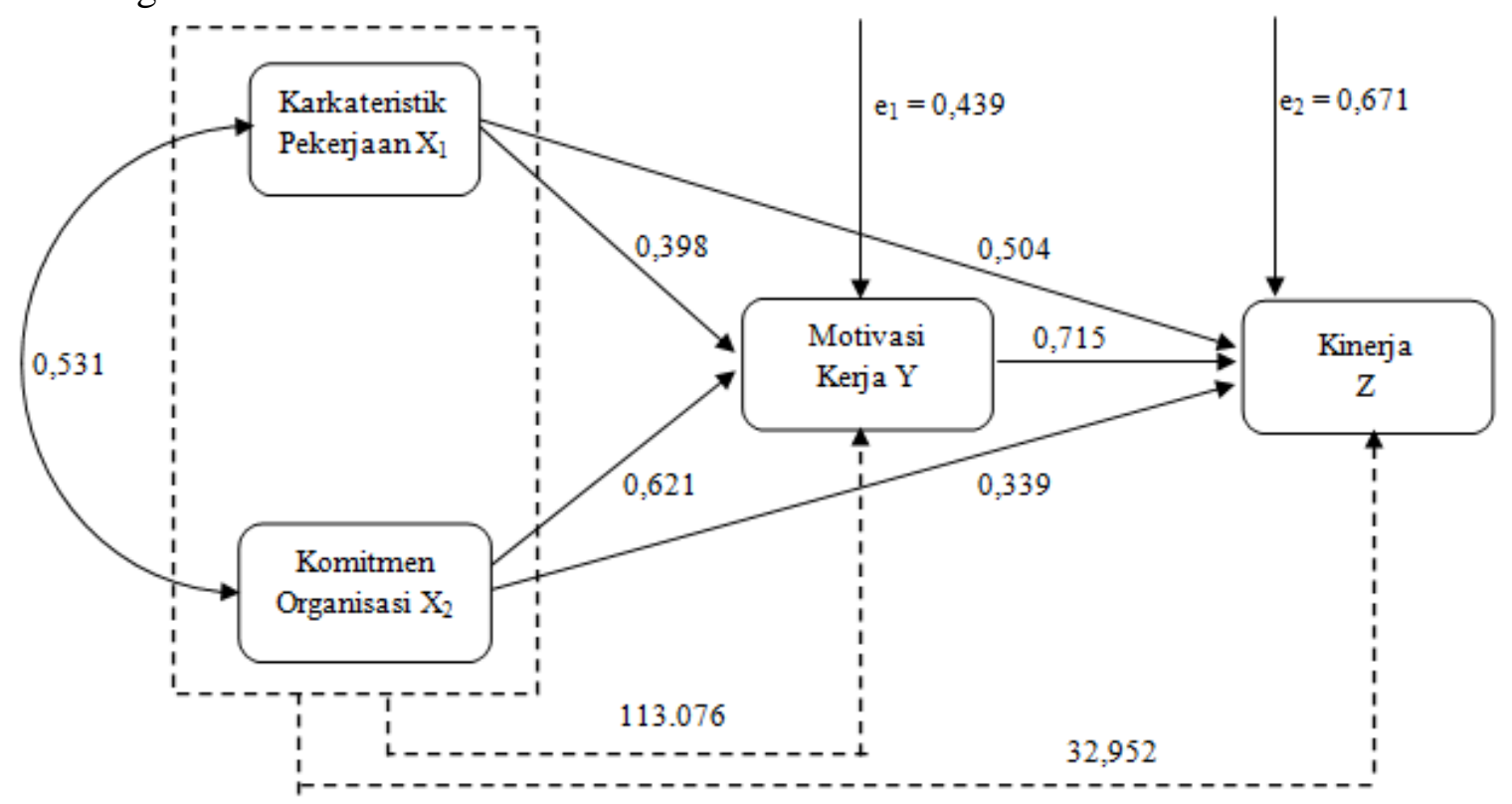

Gambar 2.Hasil Analisis Jalur

Untuk melihat pengaruh langsung dan tidak langsung, dapat dilihat pada tabel berikut:

Tabel 2. Rangkuman Koefisien Jalur Karakteristik Pekerjaan dan Komitmen

Organisasi terhadapMotivasi Kerja

\begin{tabular}{|c|c|c|c|c|c|}
\hline \multirow{2}{*}{ Variabel } & \multirow{2}{*}{ Langsung } & \multicolumn{2}{|c|}{ Tidak Langsung } & \multirow{2}{*}{$\begin{array}{c}\text { Sub } \\
\text { Total }\end{array}$} & \multirow{2}{*}{ Total } \\
\hline & & $\mathbf{X}_{1}$ & $\mathbf{X}_{2}$ & & \\
\hline Karakteristik Pekerjaan $\left(\mathrm{X}_{1}\right)$ & $15,84 \%$ & & $13,12 \%$ & $13,12 \%$ & $28.96 \%$ \\
\hline Komitmen Organisasi $\left(\mathrm{X}_{2}\right)$ & $38,56 \%$ & $13,12 \%$ & & $13,12 \%$ & $51.69 \%$ \\
\hline \multicolumn{5}{|c|}{ Pengaruh $X_{1}, X_{2}$} & $\begin{array}{l}80.65 \% \\
19.35 \%\end{array}$ \\
\hline
\end{tabular}

Sumber: Hasil proses data dari SPPS 21.0 for windwos yang diolah.

Dari hasil analisis jalur yang dilakukan diperoleh pengaruh langsung karakteristik pekerjaan terhadap motivasi kerja sebesar 15,84\%, Komitmen 
organisasi terhadap motivasi kerja sebesar $38,56 \%$ dan total pengaruh karakteristik pekerjaan dan komitmen organisasi terhadap motivasi kerja secara langsung maupun tidak langsung sebesar 80,65. Nilai tersebut menjelaskan nilai koefisien determinasi $\mathrm{R}^{2}$ Square Seperti yang tampak pada tabel berikut.

Tabel 3. Koefisien Determinasi

Model Summary

\begin{tabular}{lcrrr}
\hline Model & R & R Square & $\begin{array}{c}\text { Adjusted R } \\
\text { Square }\end{array}$ & $\begin{array}{l}\text { Std. Error of } \\
\text { the Estimate }\end{array}$ \\
\hline 1 & $.898^{\mathrm{a}}$ & .807 & .800 & 2.444 \\
\hline a. Predictors: (Constant), KomOrg_X2, KarPekerjaan_X1
\end{tabular}

Nilai R sebesar 0,898 menunjukan korelasi ganda (karakteristik pekerjaan dan komitmen organisasi) dengan motivasi. Dengan mempertimbangkan variasi Nilai $\mathrm{R}$ Square sebesar 0,807 yang menunjukan besarnya peran atau kontribusi variabel karakteristik pekerjaan dan komitmen organisasi mampu menjelaskan variabel motivasi sebesar $80,7 \%$ dan sisanya 19,3\% dipengaruhi oleh variabel lain yang tidak termasuk dalam model ini.

Tabel 4. Rangkuman Koefisien JalurKarakteristik Pekerjaan dan Komitmen Organisasi terhadapKinerja

\begin{tabular}{|c|c|c|c|c|c|}
\hline \multirow{2}{*}{ Variabel } & \multirow{2}{*}{ Langsung } & \multicolumn{2}{|c|}{ Tidak Langsung } & \multirow{2}{*}{$\begin{array}{c}\text { Sub } \\
\text { Total }\end{array}$} & \multirow{2}{*}{ Total } \\
\hline & & $\mathbf{X}_{1}$ & $\mathbf{X}_{2}$ & & \\
\hline Karakteristik Pekerjaan $\left(\mathrm{X}_{1}\right)$ & $25,4 \%$ & & $9,07 \%$ & $9,07 \%$ & $34.47 \%$ \\
\hline Komitmen Organisasi $\left(\mathrm{X}_{2}\right)$ & $11,49 \%$ & $9,07 \%$ & & $9,07 \%$ & $20.56 \%$ \\
\hline \multicolumn{5}{|c|}{ Pengaruh $\mathrm{X}_{1}, \mathrm{X}_{2}$} & $55.03 \%$ \\
\hline
\end{tabular}

Sumber: Hasil proses data dari SPPS 21.0 for windwos yang diolah.

Dari hasil analisis jalur yang dilakukan diperoleh pengaruh langsung karakteristik pekerjaan terhadap kinerja sebesar $25,4 \%$, komitmen organisasi terhadap Kinerja sebesar 11,49\% dan total pengaruh karakteristik pekerjaan dan komitmen organisasi terhadap kinerja secara langsung maupun tidak langsung sebesar 72,3. Nilai tersebut menjelaskan nilai koefisien determinasi $\mathrm{R}^{2}$ Square seperti yang tampak pada tabel berikut.

Tabel 5. Koefisien Determinasi

Model Summary

\begin{tabular}{lrrrr}
\hline Model & R & R Square & $\begin{array}{c}\text { Adjusted R } \\
\text { Square }\end{array}$ & $\begin{array}{l}\text { Std. Error of } \\
\text { the Estimate }\end{array}$ \\
\hline 1 & $.741^{\mathrm{a}}$ & .550 & .533 & 2.634 \\
\hline
\end{tabular}

a. Predictors: (Constant), KomOrg_X2, KarPekerjaan_X1

Nilai $\mathrm{R}$ sebesar 0,741 menunjukan korelasi ganda (karakteristik pekerjaan dan komitmen organisasi) dengan kinerja. Dengan mempertimbangkan variasi nilai $\mathrm{R}$ Square sebesar 0,550 yang menunjukan besarnya peran atau kontribusi variabel karakteristik pekerjaan dan komitmen organisasi mampu menjelaskan variabel kinerja sebesar 55\% dan sisanya 45\% dipengaruhi oleh variabel lain yang tidak termasuk dalam model ini. 
Kemudian dari hasil analisis jalur pengaruh langsung motivasi terhadap kinerjasebesar51,12\%, ini menunjukan bahwa motivasi secara langsung berpengaruh terhadap kinerja pegawai pada Dinas Kelautan dan Perikanan Provinsi Jambi. Hal ini menjelaskan bahwasanya apabila pegawai memilikimotivasi kerja yang tinggi dalam melaksanakan tugas pokok dan fungsinya, maka pegawai tersebut akan mampu memberikan kontribusi kerja yang baik pula dalam upaya mencapai visi dan misi organisasi. Nilai tersebut menjelaskan nilai koefisien determinasi $\mathrm{R}^{2}$ Square seperti yang tampak pada tabel berikut.

Tabel 6. Koefisien Determinasi

Model Summary

\begin{tabular}{lrrrr}
\hline Model & R & R Square & $\begin{array}{c}\text { Adjusted R } \\
\text { Square }\end{array}$ & $\begin{array}{l}\text { Std. Error of } \\
\text { the Estimate }\end{array}$ \\
\hline 1 & $.715^{\mathrm{a}}$ & .511 & .502 & 2.720 \\
\hline
\end{tabular}

a. Predictors: (Constant), Motivasi_Y

Nilai R Square sebesar 0,511 menunjukan besarnya peran atau kontribusi variabel motivasi mampu menjelaskan variabel kinerja sebesar 51,1\% dan sisanya sebesar 48,9\% dipengaruhi oleh variabellain yang tidak termasuk dalam model ini.

\section{Uji Hipotesis}

\section{a. Pengaruh Karakteristik Pekerjaan dan Komitmen Organisasi Terhadap MotivasiKerja.}

1) Pengaruh Karakteristik Pekerjaan Terhadap Motivasi Kerja.

Dari hasil output SPSS sperti yang tampak pada Tabel 1 yang dilakukan diperoleh angka nilai t hitung variabel $\mathrm{X}_{1}$ lebih besar dari nilai $\mathrm{t}$ tabel $(5.650>1.673)$, dengan tingkat signifikansi sebesar 0,000, dikarenakan angka taraf signifikansi lebih $<0.05(0.000<0.05)$ maka dapat disimpulkan bahwa karakteristik pekerjaan berpengaruh terhadap motivasikerja. Berdasarkan dari penjelasan tersebut oleh karena itu $\mathrm{H}_{0}$ ditolak dan $\mathrm{H}_{1}$ diterima, artinya karakteristik pekerjaan berpengaruh terhadap motivasikerja pegawai.

2) Pengaruh Komitmen Organisasi Terhadap Motivasi Kerja

Dari hasil output SPSS seperti yang tampak pada Tabel 1yang dilakukan diperoleh angka nilai t hitung variabel $\mathrm{X}_{2}$ lebih besar dari nilai $\mathrm{t}$ tabel $(8.816>1.673)$, dengan tingkat signifikansi sebesar 0,000, dikarenakan angka taraf signifikansi lebih $<0.05(0.000<0.05)$ maka dapat disimpulkan bahwa komitmen organisasi berpengaruh terhadap motivasi kerja. Berdasarkan dari penjelasan tersebut oleh karena itu $\mathrm{H}_{0}$ ditolak dan $\mathrm{H}_{1}$ diterima, artinya komitmen organsiasi berpengaruh terhadap motivasi kerja pegawai.

3) Pengaruh Karakteristik Pekerjaan dan Komitmen Organisasi Terhadap Motivasi KerjaSecara Simultan.

Dari uji Anova atau F test dengan menggunakan SPSS 21.0 didapat

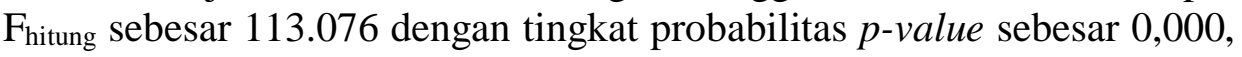
dikarenakan nilai $F_{\text {hitung }}>F_{\text {tabel }} \quad(113.076>3.16)$ sehingga dapat disimpulkan bahwa hipotesis nol $\left(\mathrm{H}_{0}\right)$ ditolak dan Hipotesa alternatif $\left(\mathrm{H}_{1}\right)$ diterima, artinya ada pengaruh signifikan antara karakteristik pekerjaandan komitmen organisasi secara bersama-sama terhadap 
motivasi kerja.Dimana besarnya sumbangan karakteristik pekerjaandan komitmen organisasi terhadap motivasikerja sebesar $80,7 \%$ dan sisanya $19,3 \%$ dipengaruhi oleh variabel lain yang tidak termasuk dalam model ini.

b. Pengaruh Karakteristik Pekerjaan dan Komitmen Organisasi Terhadap Kinerja.

1) Pengaruh Karakteristik Pekerjaan Terhadap Kinerja.

Dari hasil output SPSS sperti yang tampak pada Tabel 1 yang dilakukan diperoleh angka nilai t hitung variabel $\mathrm{X}_{1}$ lebih besar dari nilai $\mathrm{t}$ tabel (4.674> 1.673), dengan tingkat signifikansi sebesar 0,000, dikarenakan angka taraf signifikansi lebih $<0.05(0.000<0.05)$ maka dapat disimpulkan bahwa karakteristik pekerjaan berpengaruh terhadap kinerja pegawai. Berdasarkan dari penjelasan tersebut oleh karena itu $\mathrm{H}_{0}$ ditolak dan $\mathrm{H}_{1}$ diterima, artinya karakteristik berpengaruh terhadap kinerja pegawai.

2) Pengaruh Komitmen Organisasi Terhadap Kinerja

Dari hasil output SPSS seperti yang tampak pada Tabel 1 yang dilakukan diperoleh angka nilai thitung variabel $\mathrm{X}_{2}$ lebih besar dari nilai $\mathrm{t}$ tabel (3.146> 1.673), dengan tingkat signifikansi sebesar 0,003, dikarenakan angka taraf signifikansi lebih $<0.05(0.003<0.05)$ maka dapat disimpulkan bahwa komitmen organisasi berpengaruh terhadap kinerja pegawai. Berdasarkan dari penjelasan tersebut oleh karena itu $\mathrm{H}_{0}$ ditolak dan $\mathrm{H}_{1}$ diterima, artinya komitmen organisasi berpengaruh terhadap kinerja pegawai.

3) Pengaruh Karakteristik Pekerjaan dan Komitmen Organisasi Terhadap Kinerja Secara Simultan.

Dari uji Anova atau F test dengan menggunakan SPSS 21.0 didapat $F_{\text {hitung }}$ sebesar 32.952 dengan tingkat probabilitas p-value sebesar 0,000, dikarenakan nilai $F_{h i t u n g}>\quad F_{\text {tabel }}$ (32.952> 3.16) sehingga dapat disimpulkan bahwa hipotesis nol $\left(\mathrm{H}_{0}\right)$ ditolak dan Hipotesa alternatif $\left(\mathrm{H}_{1}\right)$ diterima, artinya ada pengaruh signifikan antara karakteristik pekerjaan dan komitmen organisasi secara bersama-sama terhadap kinerja pegawai.Dimana besarnya peran atau kontribusi variabel karakteristik pekerjaan dan komitmen organisasi mampu menjelaskan variabel kinerja sebesar 55\% dan sisanya $45 \%$ dipengaruhi oleh variabel lain yang tidak termasuk dalam model ini.

\section{c. Pengaruh Motivasi Kerja dan Kompensasi Terhadap Kinerja.}

Dari hasil output SPSS seperti yang tampak pada Tabel 1 yang dilakukan diperoleh angka nilai t hitung variabel $\mathrm{X}_{1}$ lebih besar dari nilai $\mathrm{t}$ tabel (7.582> 1.673), dengan tingkat signifikansi sebesar 0,000, dikarenakan angka taraf signifikansi lebih $<0.05(0.000<0.05)$ maka dapat disimpulkan bahwa motivasi kerja berpengaruh terhadap kinerja pegawai. Berdasarkan dari penjelasan tersebut oleh karena itu $\mathrm{H}_{0}$ ditolak dan $\mathrm{H}_{1}$ diterima, artinya motivasi kerja berpengaruh terhadap kinerja pegawai.

\section{PEMBAHASAN}

\section{Pembahasan Hipotesis Pertama}

Dari hasil penelitian yang telah dilakukan, adapun deskriptif karakteristik pekerjaan, komitmen organisasi, motivasi dan kinerja pegawai pada Dinas Kelautan dan Perikanan Provinsi Jambi berada pada Kriteria Cukup Baik. 
2. Pembahasan Hipotesis Kedua Karakteristik pekerjaan dan komitmen organisasi secara parsial dan simultan berpengaruh signifikan terhadap motivasi kerja.

a. Karakteristik pekerjaan berpengaruh signifikan terhadap motivasi kerja.

Karakteristik pekerjaan secara parsial memiliki pengaruh terhadap motivasi kerja pegawai. Hasil penelitian ini menunjukan hasil yang sama dengan penelitian yang dilakukan oleh Wulandari, S., Sulianti, D., dan Sunardi (2015) dimana hasil penelitiannya menunjukan bahwa karakteristik dapat berpengaruh terhadap motivasi kerja. Karakteristik pekerjaan merupakan upaya mengidentifikasi karakteristik tugas dari suatu pekerjaan, bagaimana karakteristik itu digabung untuk membentuk pekerjaan yang berbeda dengan hubungannya dengan motivasi, kepuasan kerja dan kinerja karyawan (Frismandiri, D, 2007).

Hasil penelitian menunjukkan bahwa karakteristik pekerjaan yang kuat mampu meningkatkan motivasi pada pegawai. Bentuk motivasi yang dirasakan pegawai dengan adanya karakteristik pekerjaan yang kondusif dapat berupaTKD yang diberikan,lingkungan kerja yang kondusif sehingga mampu memotivasi pegawai dalam bekerja.

b. Komitmen organisasi berpengaruh signifikan terhadap motivasi kerja.

Komitmen organisasi secara parsial memiliki pengaruh terhadap motivasi kerja pegawai. Komitmen organisasi merupakan identifikasi dan keterlibatan seseorang yang relatif kuat terhadap organisasi. Komitmen organisasional adalah keinginan anggota organisasi untuk tetap mempertahankan keanggotaannya dalam organisasi dan bersedia berusaha keras bagi pencapaian tujuan organisasi (Sopiah, 2008). Dalam manajemen organisasi diperlukan hubungan yang lebih baik dan keinginan para karyawan yaitu saling mencintai para karyawan yang mau bekerja dan mempunyai komitmen organisasi yang tinggi.

c. Karakteristik pekerjaan dan komitmen organisasi secara simultan berpengaruh signifikan terhadap motivasi kerja.

Karakteristik pekerjaan dengan indikator keanekaragaman tugas, indentitas tugas, pentingnya tugas, otonomi dan umpan balik dan komitmen organisasi dengan indikator affective commitment, continuance commitment, dan normative commitment berpengaruh terhadap motivasikerja secara simultan dengan indikatorfisiologis, keamanan, sosial, penghargaan dan aktualisasi diri. Artinya apabila pegawai memiliki karakteristik pekerjaan yang kuat serta didukung pula dengan komitmen organisasi yang tinggi maka akan mampu meningkatkan motivasi pada pegawai.

3. Pembahasan Hipotesis Ketigakarakteristik pekerjaan dan komitmen organisasi secara parsial dan simultan berpengaruh signifikan terhadap kinerja pegawai.

a. Karakteristik pekerjaan berpengaruh signifikan terhadap kinerja.

Karakteristik pekerjaan secara parsial memiliki pengaruh terhadap kinerja pegawai. Hasil penelitian ini menunjukan hasil yang sama dengan penelitian yang dilakukan oleh Lubis, Y (2012), Wulandari, S., Sulianti, D., dan Sunardi (2015), Zunaidah (2010), dan Frismandiri, D (2007) yang menyatakan bahwa karakteristik pekerjaan mempunyai pengaruh signifikan terhadap kinerja dan karakteristik pekerjaan memberikan konstribusi yang cukup kuat pada kinerja. 
Menurut Robbins (2009:211), karakteristik pekerjaan merupakansalah satu factor yang dapat mempengaruhi kinerja karyawan. Karakteristik pekerjaan menetukan kesesuaian orang dengan suatu bidang pekerjaan tertentu dan memungkinkan seseorang untuk lebih berhasil dalam bidang yang di tekuninya. Dengan pemahaman terhadap karakteristik pekerjaan diharapkan karyawan tersebut akan semakin berorientasi dibidang pekerjaannya. Karyawan akan menekuni pekerjaan dengan konsentrasi dan tanggung jawab yang di sertai perasaan senang sampai di peroleh hasilyang memuaskan. Jika seorang karyawan memiliki karakteristik yang sesuai dengan pekerjaanya maka kinerjanya akan meningkat.

b. Komitmen organisasi berpengaruh signifikan terhadap kinerja.

Komitmen organisasi secara parsial memiliki pengaruh terhadap kinerja pegawai. Hasil penelitian ini menunjukan hasil yang sama dengan penelitian yang dilakukan oleh Frismandiri, D (2007), Safrizal, Said, M., dan Syafruddin, C (2014), Abrivianto, P.O., Swasto, B., dan Utami, H.N. (2014), dan Suwardi dan Utomo, J. (2011) dimana hasil penelitiannya menyatakan secara signifikan dan positif kinerja dipengaruhi oleh komitmen organisasi. Artinya apabila pegawai memiliki komitmen yang tinggi terhadap organisasi tempat mereka bernaung, maka dengan senantiasa pegawai tersebut akan mampu memberikan hasil kerja yang optimal.

Komitmen organisasi merupakan keterikatan seseorang untuk melakukan suatu pekerjaan dengan adanya kemauan yang tinggi tanpa ada paksaan atau tekanan dari teman sejawat maupun dari atasan dalam keterlibatannya yang harus dilakukan merupakan suatu kebanggaan dan tanggung jawab untuk meningkatkan kinerja suatu organisasi di mana tempatnya bekerja. Komitmen organisasional dipandang sebagai suatu orientasi nilai terhadap organisasi yang menunjukkan individu sangat memikirkan dan mengutamakan pekerjaan dan organisasinya. Individu akan berusaha memberikan segala usaha yang dimilikinya dalam rangka membantu organisasi mencapai tujuannya.

c. Karakteristik pekerjaan dan komitmen organisasisecara simultan berpengaruh signifikan terhadap kinerja.

Karakteristik pekerjaan dengan indikator keanekaragaman tugas, indentitas tugas, pentingnya tugas, otonomi dan umpan balik dan komitmen organisasi dengan indikator affective commitment, continuance commitment, dan normative commitment berpengaruh terhadap kinerja secara simultan dengan indikatorkemampuan teknis, kemampuan konseptual, dan kemampuan hubungan interpersonal. Artinya apabila pegawai memiliki karakteristik pekerjaan yangkuat serta didukung pula dengan komitmen organisasi yang tinggi maka akan mampu memberikan konstribusi yang cukup kuat pada kinerja.

\section{Pembahasan Hipotesis Keempatmotivasi kerja berpengaruh signifikan terhadap kinerja pegawai.}

Dari pengujian hipotesis yang dilakukan diketahui jika motivasi kerja secara parsial memiliki pengaruh terhadap kinerja pegawai. Hasil penelitian ini dapat mendukung atau memperkuat teori yang ada, yang menyatakan bahwa apabila dengan memiliki motivasi kerja yang tinggi maka akan menciptakan kegairahan seseorang, agar mau bekerja sama, bekerja efektif dan terintegrasi dengan segala daya upayanya untuk mencapai tujuan (Hasibuan, 2009). 
Selain itu hasil penelitian ini juga menunjukan hasil yang sama dengan penelitian yang dilakukan oleh Wulandari, S., Sulianti, D., dan Sunardi (2015), Abrivianto, P.O., Swasto, B., dan Utami, H.N. (2014), Suwardi dan Utomo, J. (2011), dan Asyenda, Y (2013)mengungkapkan bahwa motivasi kerja juga akan mampu mempengaruhi dan meningkatkan kinerja. Artinya dengan memiliki motivasi kerja yang tinggi akan mampu memberikan hasil kerja yang maksimal. Motivasi adalah dorongan yang ada dalam diri manusia yang menyebabkan ia melakukan sesuatu (Sopiah, 2008). Dalam kehidupan manusia selalu mengadakan bermacam-macam aktifitas. Salah satu aktivitas itu diwujudkan dalam gerakan-gerakan yang dinamakan kerja.

Maslow dalam Mangkunegara(2014) mengatakan bahwa motivasi merupakan Kondisi jiwa yang mendorong seseorang dalam mencapai prestasinya secara maksimal. Motivasi merupakan factor yang mempengaruhi semangatdan kegairahan kerja pegawai untuk berperan serta secara aktif dalam proses kerja sehingga akan mampu memberikan hasil kerja yang lebih optimal.

5. Pembahasan Hipotesis Kelimakarakteristik pekerjaan dan komitmen organisasi melalui motivasi kerja berpengaruh terhadap kinerja pegawai.

Dari pengujian hipotesis yang dilakukan diketahui karakteristik pekerjaan dan komitmen organisasi melalui motivasi kerja memiliki pengaruh terhadap kinerja pegawai. Motivasi sebagai prosesyang ikut menentukan intensitas, arah, dan ketekunan individu dalam usaha mencapai sasaran. Motivasi sebagai pemberian motif, penimbulan motif atau hal yang menimbulkan dorongan atau keadaan yang menimbulkan dorongan. Setiap individu memerlukan motivasi dalam bekerja. Adanya motivasi akan menimbulkan semangat kerja karena motivasi merupakan suatu dorongan dalam diri seseorang untuk melakukan sesuatu. Dengan kebutuhan yang berbeda-beda maka setiap perilaku individu dalam mencapai tujuan akan berbeda motivasinya (Robbins, 2009:213). Hasil penelitian menunjukkan bahwa karakteristik pekerjaan yang kuat mampu meningkatkan motivasi pada pegawai. Bentuk motivasi yang dirasakan pegawai dengan adanya karakteristik pekerjaan yang kondusif berupa TKD yang diberikan kepada pegawai akan dapat sangat mendukung kinerja pegawai.

\section{SIMPULAN DAN SARAN}

Berdasarkan hasil penelitian dan pembahasan, maka dapat disimpulkan sebagai berikut:

1. Karakteristik pekerjaan, komitmen organisasi, motivasi dan kinerja pegawai pada Dinas Kelautan dan Perikanan Provinsi Jambi dalam kondisi yang cukup baik.

2. Karakteristik pekerjaan dan komitmen organisasi memiliki pengaruh yang signifikan terhadap motivasi kerja pegawai pada Dinas Kelautan dan Perikanan Provinsi Jambi, baik secara parsial maupun secara simultan.

3. Karakteristik pekerjaan dan komitmen organisasi memiliki pengaruh yang signifikan terhadap kinerja pegawai pada Dinas Kelautan dan Perikanan Provinsi Jambi, baik secara parsial maupun secara simultan.

4. Motivasi kerja memiliki pengaruh yang signifikan terhadap kinerja pegawai pada Dinas Kelautan dan Perikanan Provinsi Jambi.

5. Karakteristik pekerjaan dan komitmen organisasi melalui motivasi kerja memiliki pengaruh terhadap kinerja pegawai pegawai pada Dinas Kelautan dan 
Perikanan Provinsi Jambi, baik secara langsung maupun tidak langsung melalui motivasi kerja.

\section{DAFTAR PUSTAKA}

Abrivianto, P.O., Swasto, B., dan Utami, H.N. (2014)."Pengaruh Motivasi Kerja dan Komitmen Organisasional Terhadap Kinerja Karyawan (Studi Pada Karyawan Bagian HRD PT. Arthawena Sakti Gemilang Malang)".Jurnal Administrasi Bisnis (JAB) 7, no. 2.

Asnawi, T. (2016). Manajemen Sumber Daya Manusia. Palembang: Citrabooks Indonesia.

Asyenda, Y. (2013). Pengaruh Motivasi Kerja dan Disiplin Kerja Terhadap Kinerja PNS (Studi Kasus BAPPEDA Kota Malang).

Frismandiri, D. (2007). Analisis Pengaruh Karakteristik Pekerjaan, Kepuasan Kerja, dan Komitmen Terhadap Kinerja Karyawan. Jurnal Modernisasi, Volume 3, No. 2.

Ghozali, I. (2012). Aplikasi Analisis Multivariate Dengan Program IBM SPSS 19. Semarang: Undip.

Hasibuan, M.S.P. (2009). Manajemen Sumber Daya Manusia. Jakarta: Bumi Aksara.

Lubis, Y. (2012). Pengaruh Karakteristik Individu, Karakteristik Pekerjaan, Iklim Organisasi Terhadap Kepuasan dan Kinerja Karyawan. Jurnal Trikonomika, Volume 11, No. 2.

Luthans, F. (2006).Perilaku Organisasi, (Alih Bahasa V.A Yuwono, dkk), Edisi Bahasa Indonesia, Yogyakarta: ANDI.

Mangkunegara, A.P. (2011). Perencanaan dan Pengembangan Sumber Daya Manusia. Bandung: Refika Aditama.

Rivai, V dan Sagala, E.J. (2009).Manjemen Sumber Daya Manusia Untuk Perusahaan Dari Teori Ke Praktik. Jakarta: RajaGrafindo

Robbins, S. (2009).Motivation and personality. New York: Harper \& Row.

Robbins, Stepehen P \& Judge, Timothy A. (2015).Perilaku Organisasi. Jakarta: PT. Salemba Empat.

Safrizal, Said, M., dan Syafruddin, C. (2014). Pengaruh Budaya Kerja, Kemampuan dan Komitmen Pegawai Terhadap Kinerja Pegawai Serta Dampaknya Pada Kinerja Dinas Pertambangan dan Energi Aceh. Jurnal Manajemen. Volume 3, No. 2.

Simamora, H. (2006). Manajemen Sumber Daya Manusia, edisi keempat, cetakan pertama, Penerbit: YKPN: Yogyakarta

Singarimbun, M \& Effendi, S. (2012). Metode Penelitian Survey. Jakarta: LP3ES. Sopiah.(2008). Perilaku Organisasional. Yogyakarta: Andi.

Sugiyono.(2012). Metode Penelitian Bisnis. Bandung: Alfabeta.

Sunyoto, D. (2011). Metodologi Penelitian Ekonomi. Yogyakarta: CAPS.

Sutrisno, E. (2012). Manajemen Sumber Daya Manusia. Jakata: Kencana Prenada Media Group.

Suwardi dan Utomo, J. (2011). "Pengaruh Motivasi Kerja, Kepuasan Kerja dan Komitmen Organisasional Terhadap Kinerja Pegawai (Studi Pada Pegawai Setda Kabupaten Pati)". Jurnal Analisis Manajemen5, no. 1.

Triatna, C. (2015). Perilaku Organisasi dalam Pendidikan. Bandung: Remaja Rosdakarya Offset.

Wibowo.(2014). Perilaku Dalam Organisasi. Jakarta: RajaGrafindo Persada. 
Wulandari, S., Sulianti, D., dan Sunardi.(2015). Pengaruh Lingkungan Kerja dan Karakteristik Pekerjaan Terhadap Kinerja Karyawan Dengan Motvasi Kerja Sebagai Variabel Intervening Pada karyawan Perusahaan Batik Di Banyuwangi.Artikel Ilmiah Mahasiswa 2015.

Zunaidah.(2010). Pengaruh Kompensasi dan Karakteristik Pekerjaan Terhadap Kinerja Pegawai.Jurnal Manajemen dan Bisnis Sriwijaya, Vol. 8, No. 15. 